\title{
The Garden Site (41CE480) on Bowles Creek, Cherokee County, Texas
}

Kevin Stingley

Texas Archeological Stewardship Network, Texas Historical Commission

Timothy K. Perttula

Heritage Research Center, Stephen F. Austin State University

Follow this and additional works at: https://scholarworks.sfasu.edu/ita

Part of the American Material Culture Commons, Archaeological Anthropology Commons, Environmental Studies Commons, Other American Studies Commons, Other Arts and Humanities Commons, Other History of Art, Architecture, and Archaeology Commons, and the United States History Commons

Tell us how this article helped you.

This Article is brought to you for free and open access by the Center for Regional Heritage Research at SFA ScholarWorks. It has been accepted for inclusion in Index of Texas Archaeology: Open Access Gray Literature from the Lone Star State by an authorized editor of SFA ScholarWorks. For more information, please contact cdsscholarworks@sfasu.edu. 


\section{The Garden Site (41CE480) on Bowles Creek, Cherokee County, Texas}

Creative Commons License

(c) (i) (8)

This work is licensed under a Creative Commons Attribution-NonCommercial 4.0 International License 


\section{The Garden Site (41CE480) on Bowles Creek, Cherokee County, Texas}

Kevin Stingley and Timothy K. Perttula

\section{Introduction}

Recent archaeological investigations in the Bowles Creek Valley in the Neches River basin in East Texas (Figure 1) have identified a number of ancestral Caddo habitation sites (Perttula and Stingley 2016a, 2016b, 2017; Perttula et al. 2016). The Garden site (41CE480) is another of these Caddo sites, and was probably a farmstead occupied by one or a few families for a generation or two.

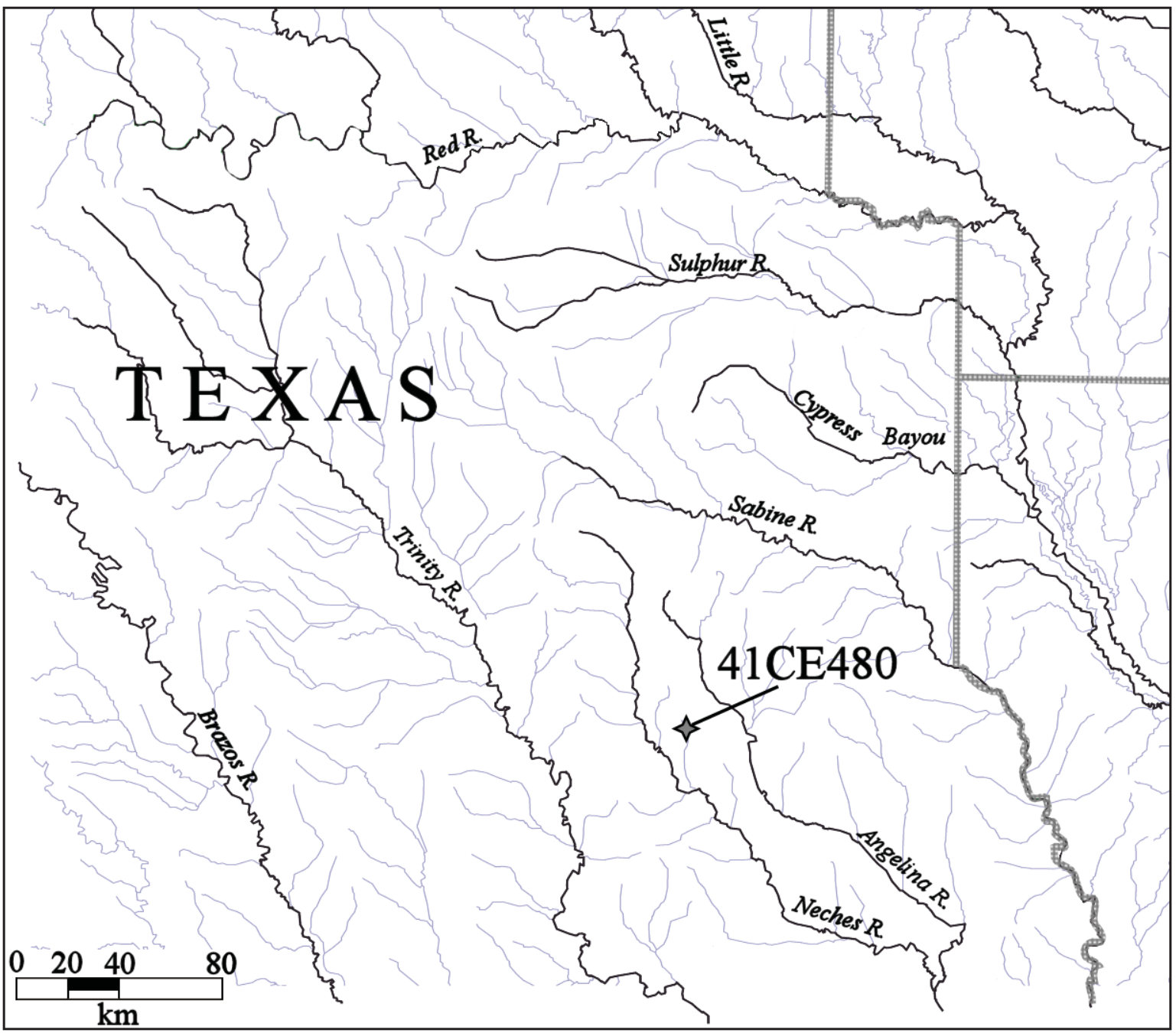

Figure 1. Location of the Garden site (41CE480) in East Texas. 
The Garden site is on a grass and tree-covered upland ridge (385 feet amsl, Figure $2 \mathrm{a}$ ) between the Turkey Creek and Bowles Creek valleys; Turkey Creek is west of the site and flows south to merge with Bowles Creek about $1.4 \mathrm{~km}$ south of the site. Lithic and ceramic artifacts have been noted on the surface over a ca. $900+$ square meter area of the landform.

\section{Site Investigations}

In addition to a surface reconnaissance of the Garden site, and the obtaining of a small surface collection of artifacts $(n=7)$, a total of 10 shovel tests have been excavated in the eastern part of the site to determine the horizontal and vertical extent of any subsurface archaeological deposits (Figure 2b). Five of these shovel tests contain ancestral Caddo ceramic and lithic artifacts between 12-26 cm bs in Nacogdoches fine sandy loam sediments (Table 1). The density of artifacts in these shovel tests ranges from only 1-5, with a mean density of 3.4 artifacts per positive shovel test; this density is equivalent to ca. 27.2 artifacts per square meter of archaeological deposits.

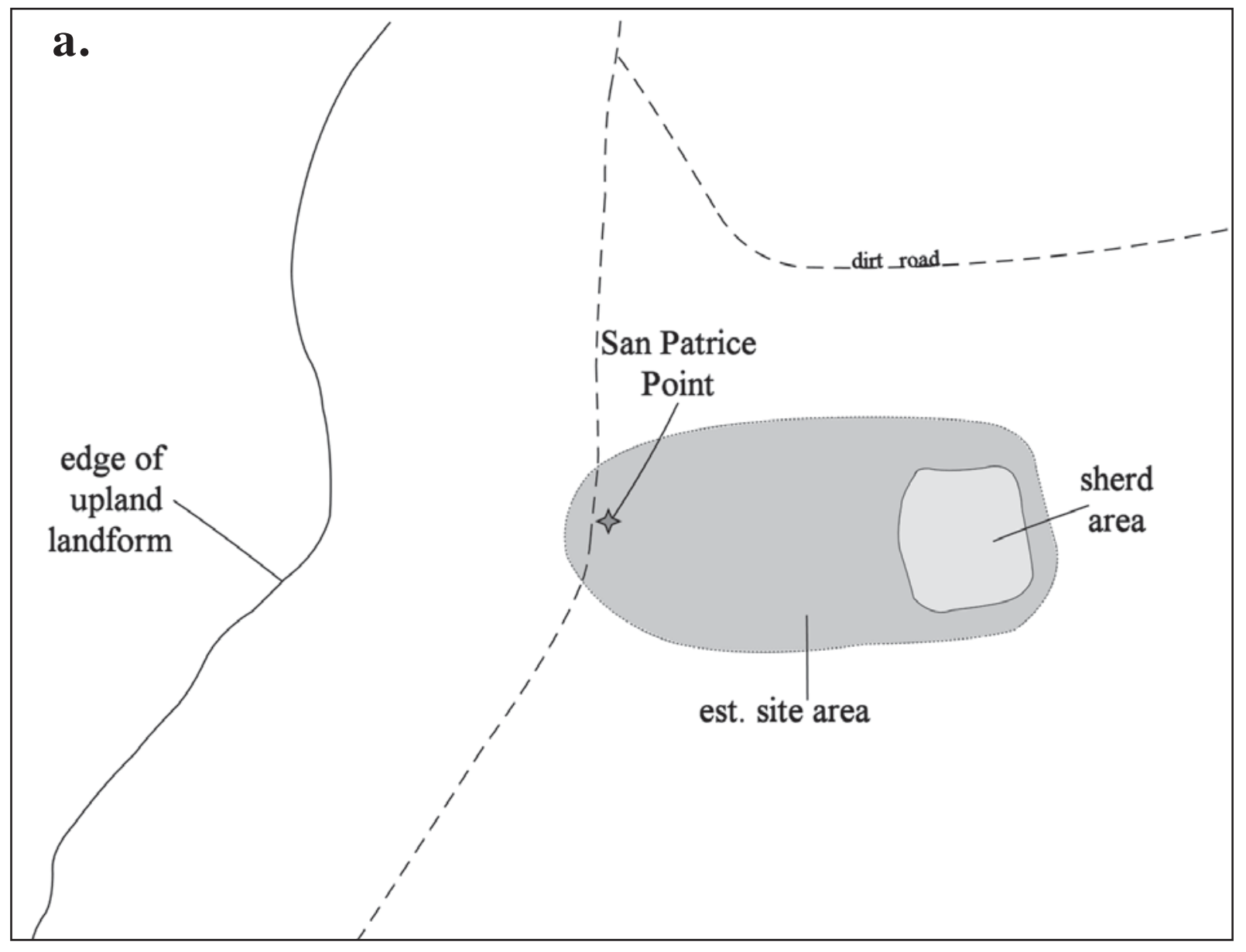

Figure 2. The Garden site (41CE480): a, overall site area; b, shovel test locations in the area of the site with Caddo ceramic sherds. 


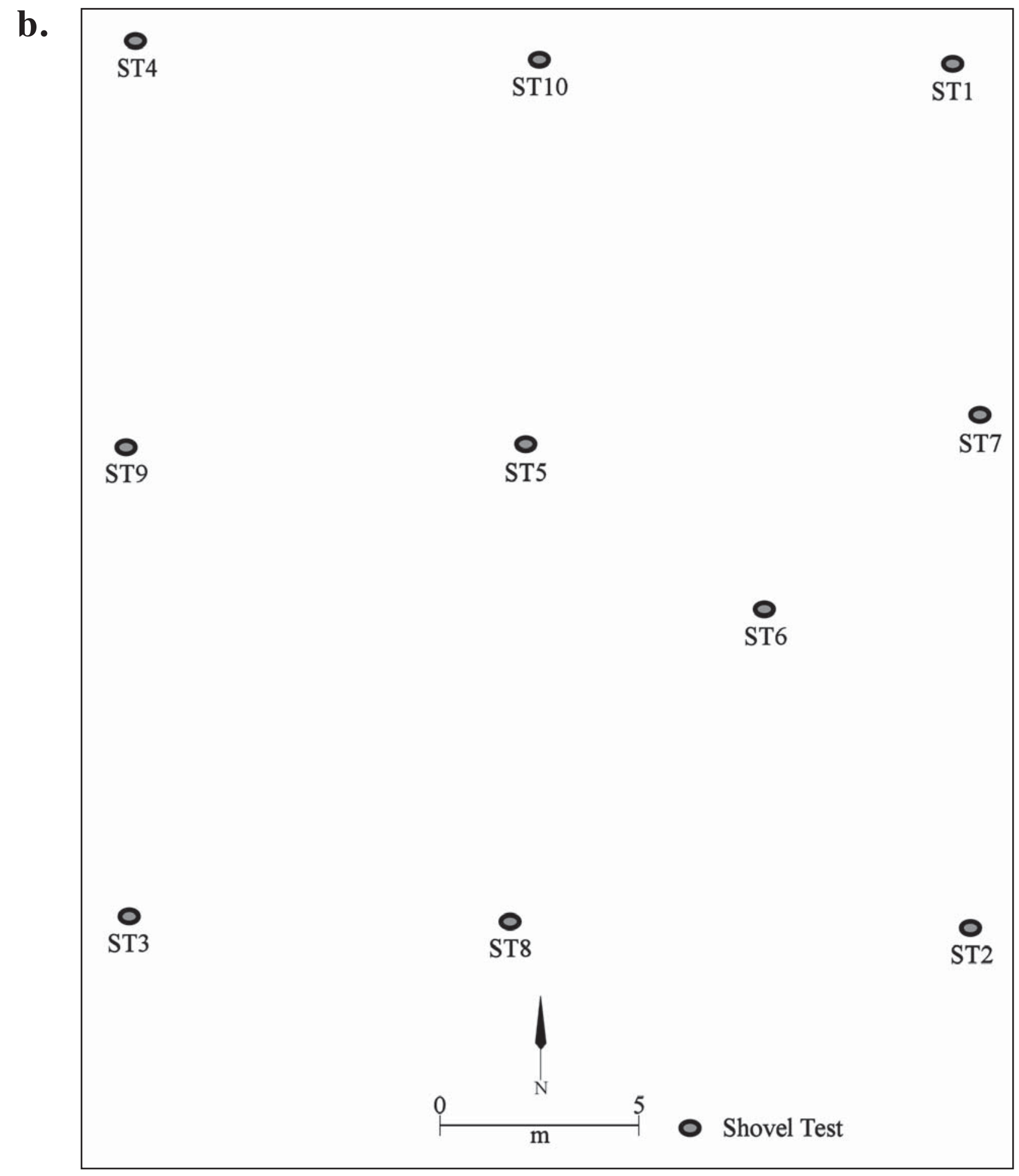

Figure 2., cont. 
Table 1. Artifacts recovered from the surface and shovel tests at the Garden site.

\begin{tabular}{llllll}
\hline Context & Plain Sherd & Decorated Sherd & Dart Point & $\begin{array}{l}\text { Lithic } \\
\text { Debris }\end{array}$ \\
\hline Surface & 2 & 3 & 1 & 1 & N \\
ST 1 & 4 & 1 & - & - & 5 \\
ST 4 & 3 & 2 & - & - & 5 \\
ST 5 & 1 & - & - & 1 & 2 \\
ST 6 & 2 & - & - & - & 3 \\
ST 10 & 2 & 1 & 1 & 2 & 24 \\
\hline Totals & 14 & 7 & & & - \\
\hline
\end{tabular}

\section{Recovered Artifacts}

A San Patrice point, dating from ca. 10,500-9800 years B.P., was found on the surface in the western part of the Garden site (Figure 3; see also Figure 2a). Based on the suggested chronological sequence for East Texas dart points proposed by Story (1990:Figure 32), the Early Archaic dart point sequence begins with Dalton and San Patrice points, although both point types were first made beginning about 10,500 years B.P. (Koldehoff and Walthall 2009; Morse 1997; Ray et al. 2009), and consequently are often considered to be diagnostic of the Late Paleoindian period in the broader region. Recent radiocarbon dates from the Big Eddy site in southwest Missouri indicates both points were made and used until ca. 9800 years B.P. (Ray et al. 2009:160), in the early years of the Late Paleoindian-Early Archaic technological, subsistence, and settlement/mobility transition (cf. Bousman et al. 2002:989).

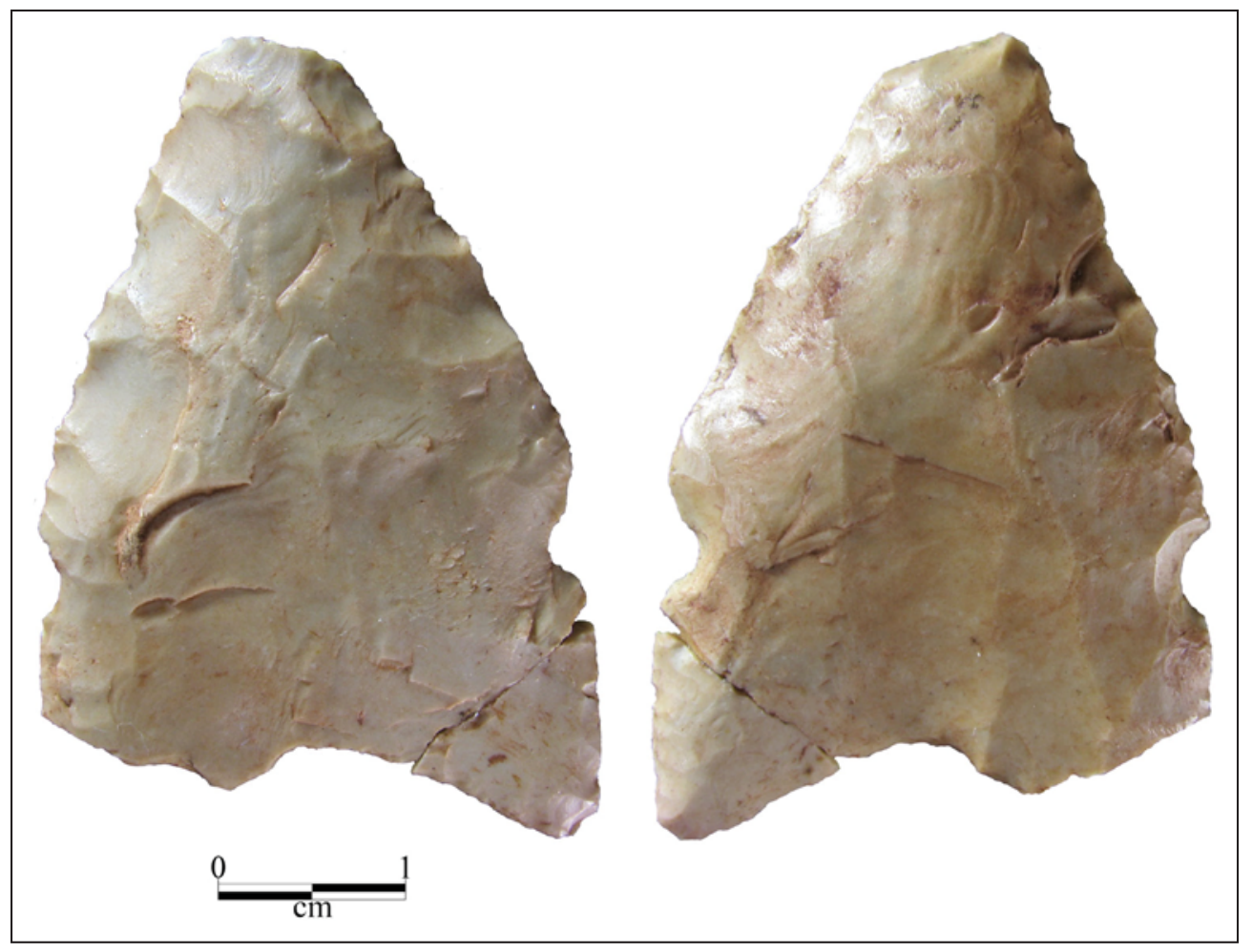

Figure 3. San Patrice point from the Garden site (41CE480). 
The point is made from a non-local light gray chert; although the source area of this chert has not been determined, it is likely that it originated in the chert-bearing formations of Central Texas. This point has a resharpened blade and tip, as well as small and shallow side notches; one basal ear has been snapped off (see Figure 3). The blade has shallow thinning or fluting scars on both faces, and these scars range from 6-9 $\mathrm{mm}$ in width. They extend $19.2 \mathrm{~mm}$ in length from the base onto the blade. The concave base has evidence of grinding. The San Patrice point is $44.0 \mathrm{~mm}$ in length, $27.0 \mathrm{~mm}$ in width above the shallow side notches, and is $28.9 \mathrm{~mm}$ in width at the basal ears. The point is $6.3 \mathrm{~mm}$ in thickness.

There are two pieces of lithic debris in the artifact assemblage from the Garden site (see Table 1). These are non-cortical pieces of a local petrified wood and a non-local piece of gray chert.

About 90 percent of the ceramic sherds recovered to date from the Garden site are from grog-tempered vessels (Table 2). The remainder are from bone-tempered vessels. These proportions are not that different from other Bowles Creek valley sites (see Perttula et al. 2016:Table 15). There are no fine ware sherds in the small ceramic assemblage.

Table 2. Ceramic wares from the Garden site.

\begin{tabular}{lccc}
\hline Ware & Grog-tempered & Bone-tempered & N \\
\hline Plain & 13 & 1 & 14 \\
Utility & 6 & 1 & 7 \\
\hline Totals & 19 & 2 & 21 \\
\hline
\end{tabular}

The plain to decorated sherd ratio (P/DR) of this small sherd assemblage is 2.0, considerably different from the Historic Caddo Allen phase components at the nearby Bowles Creek (41CE475), Cornfield (41CE476), and Peach Orchard (41CE477) sites; at these sites the P/DR ranges from 0.40-0.47 (Perttula et al. 2016:Table 15). The absence of Patton Engraved sherds from the Garden site ceramic assemblage is also notable - even though the assemblage size is rather small-and these two facts suggest that the Caddo occupation at the Garden site predates ca. A.D. 1680.

The seven decorated sherds have brushed $(n=5)$, incised $(n=1)$, and fingernail punctated $(n=1)$ decorative elements. The brushed sherds are from jars have parallel brushed marks, the incised sherd has a single straight incised line, and the last decorated sherd has a row of fingernail punctations. The proportion of brushed sherds among the decorated sherds from the Garden site is 71 percent, suggesting the ancestral Caddo occupation likely dates to the latter part of the Late Caddo period (ca. A.D. 1560-1680). The proportion of brushed sherds in the decorated sherd ceramic assemblages of nearby Historic Caddo Allen phase sites on Bowles Creek range from 81.1-83.5 percent (Perttula et al. 2016:Table 15).

\section{Summary and Conclusions}

January 2016 archaeological investigations at the Garden site (41CE480) on an upland landform in the Bowles Creek valley in East Texas indicate that the small site has both Late Paleoindian-Early Archaic and Late Caddo periods of use, with the Caddo occupation being the more substantial. The Late Paleoindian-Early Archaic period of use is marked by a single San Patrice point, made from a non-local lithic raw material, found on the surface on the western part of the landform. The Late Caddo occupation covers ca. 625 square meters, based on both surface reconnaissance and shovel testing, with archaeological 
deposits ranging only from $12-26 \mathrm{~cm}$ bs. Artifacts recovered in the surface collections and shovel tests include ceramic sherds $(\mathrm{n}=21)$ from grog- and bone-tempered vessels and two pieces of lithic debris. About 33 percent of the ceramic sherds have decorations, including brushed, incised, and fingernail punctated elements, and 71 percent of these decorated sherds are from brushed utility ware vessels.

\section{Acknowledgments}

Thanks to Lonnie Lindsey, the landowner, for permission to conduct these archaeological investigations at the Garden site. Thanks also to Bo Nelson, who found the San Patrice point during a cursory surface reconnaissance. Lance Trask prepared the figures in this article.

\section{References Cited}

Bousman, C. B., M. B. Collins, P. Goldberg, T. Stafford, J. Guy, B. W. Baker, D. G. Steele, M. Kay, A. Kerr, G. Fredlund, P. Dering, V. Holliday, D. Wilson, W. Gose, S. Dial, P. Takac, R. Balinksy, M. Masson, and J. F. Powell 2002 The Palaeoindian-Archaic transition in North America: new evidence from Texas. Antiquity 76:980-990.

Koldehoff, B. and J. A. Walthall

2009 Dalton and the Early Holocene Midcontinent: Setting the Stage. In Archaic Societies: Diversity and Complexity across the Midcontinent, edited by T. E. Emerson, D. L. McElrath, and A. C. Fortier, pp. 137-151. State University of New York Press, Albany.

Morse, D. F.

1997 Sloan: A Paleoindian Dalton Cemetery in Arkansas. Smithsonian Institution Press, Washington, D.C.

Perttula, T. K. and K. Stingley

2016a Additional Material Culture Remains from the Bowles Creek Site (41CE475) in Cherokee County, Texas. Journal of Northeast Texas Archaeology 67:7-14.

2016b Analysis of the Recovered Artifacts from the Controlled Surface Collection at the Peach Orchard Site (41CE477), Cherokee County, Texas. Journal of Northeast Texas Archaeology 70:91-110.

2017 Renewed Archaeological Investigations at the Bowles Creek (41CE475), Cornfield (41CE476), and Peach Orchard (41CE477) Sites in the Bowles Creek Valley, Cherokee County, Texas. Journal of Northeast Texas Archaeology 71, this volume.

Perttula, T. K., K. Stingley, and M. Walters

2016 Historic Caddo Archaeological Sites in Cherokee County, Texas. Journal of Northeast Texas Archaeology 65:1-24.

Ray, J. H., N. H. Lopinot, and E. R. Hajic

2009 Archaic Prehistory of the Western Ozarks of Southwest Missouri. In Archaic Societies: Diversity and Complexity across the Midcontinent, edited by T. E. Emerson, D. L. McElrath, and A. C. Fortier, pp. 155-197. State University of New York Press, Albany.

Story, D. A.

1990 Cultural History of the Native Americans. In The Archeology and Bioarcheology of the Gulf Coastal Plain, by D. A. Story, J. A. Guy, B. A. Burnett, M. D. Freeman, J. C. Rose, D. G. Steele, B. W. Olive, and K. J. Reinhard, pp. 163-366. 2 Vols. Research Series No. 38. Arkansas Archeological Survey, Fayetteville. 